\title{
Recent extreme light sea ice years in the Canadian Arctic Archipelago: 2011 and 2012 eclipse 1998 and 2007
}

\author{
S. E. L. Howell ${ }^{1}$, T. Wohlleben ${ }^{2}$, A. Komarov ${ }^{3,4}$, L. Pizzolato ${ }^{5}$, and C. Derksen ${ }^{1}$ \\ ${ }^{1}$ Climate Research Division, Environment Canada, Toronto, Canada \\ ${ }^{2}$ Canadian Ice Service, Environment Canada, Ottawa, Canada \\ ${ }^{3}$ Department of Electrical and Computer Engineering, University of Manitoba, Winnipeg, Canada \\ ${ }^{4}$ Centre for Earth Observation Science, University of Manitoba, Winnipeg, Canada \\ ${ }^{5}$ Department of Geography and Environmental Management, University of Waterloo, Waterloo, Canada
}

Correspondence to: S. E. L. Howell (stephen.howell@ec.gc.ca)

Received: 20 February 2013 - Published in The Cryosphere Discuss.: 28 March 2013

Revised: 10 October 2013 - Accepted: 19 October 2013 - Published: 15 November 2013

\begin{abstract}
Remarkably low mean September sea ice area in the Canadian Arctic Archipelago (CAA) was observed in $2011\left(146 \times 10^{3} \mathrm{~km}^{2}\right)$, a record-breaking level that was nearly exceeded in $2012\left(150 \times 10^{3} \mathrm{~km}^{2}\right)$. These values were lower than previous September records set in 1998 $\left(200 \times 10^{3} \mathrm{~km}^{2}\right)$ and $2007\left(220 \times 10^{3} \mathrm{~km}^{2}\right)$, and are $\sim 60 \%$ lower than the 1981-2010 mean September climatology. In this study, the processes contributing to the extreme light years of 2011 and 2012 were investigated, compared to previous extreme minima of 1998 and 2007, and contrasted against historic summer seasons with above average September ice area. The 2011 minimum was associated with positive June through September (JJAS) surface air temperature (SAT) and net solar radiation $\left(K^{*}\right)$ anomalies that facilitated rapid melt, coupled with atmospheric circulation that restricted multi-year ice (MYI) inflow from the Arctic Ocean into the CAA. The 2012 minimum was also associated with positive JJAS SAT and $K^{*}$ anomalies with coincident rapid melt, but further ice decline was temporarily mitigated by atmospheric circulation which drove Arctic Ocean MYI inflow into the CAA. Atmospheric circulation was comparable between 2011 and 1998 (impeding Arctic Ocean MYI inflow) and 2012 and 2007 (inducing Arctic Ocean MYI inflow). However, preconditioning was more apparent leading up to 2011 and 2012 than 1998 and 2007. The rapid melt process in 2011 and 2012 was more intense than observed in 1998 and 2007 because of the thinner ice cover being more susceptible to anomalous thermodynamic forcing. The thinner sea ice cover within the CAA in recent years has also
\end{abstract}

helped counteract the processes that facilitate extreme heavy ice years. The recent extreme light years within the CAA are associated with a longer navigation season within the Northwest Passage.

\section{Introduction}

Prior to the Arctic melt season of 2012, perhaps the most striking Arctic sea ice event in the passive microwave satellite era since 1979 was when the mean September Arctic sea ice extent and area fell to record lows of $4.3 \times 10^{6} \mathrm{~km}^{2}$ and $2.78 \times 10^{6} \mathrm{~km}^{2}$, respectively (NASATeam; Cavalieri et al., 1996), in 2007 (Stroeve et al., 2008). This dramatic loss of ice during 2007 was linked to anomalously high sea level pressure (SLP) over the Beaufort Sea and Canadian Basin and anomalously low SLP over eastern Siberia that transported ice out of the Arctic (Ogi et al., 2008; Wang et al., 2009), together with high surface air temperature (SAT) over the central Arctic (Comiso et al., 2008) and the increased bottom melt of sea ice (Perovich et al., 2008). Years of gradual thinning of the Arctic sea ice made it susceptible to the 2007 anomalous forcing events (Maslanik et al., 2007; Lindsay et al., 2009); over the past three decades the Arctic Ocean's thick multi-year ice (MYI) has been gradually replaced with thinner firstyear ice (FYI) (Maslanik et al., 2011). In 2012, mean September sea ice extent and area fell to $3.61 \times 10^{6} \mathrm{~km}^{2}$ and $2.11 \times 10^{6} \mathrm{~km}^{2}$, respectively (NASATeam; Cavalieri et 

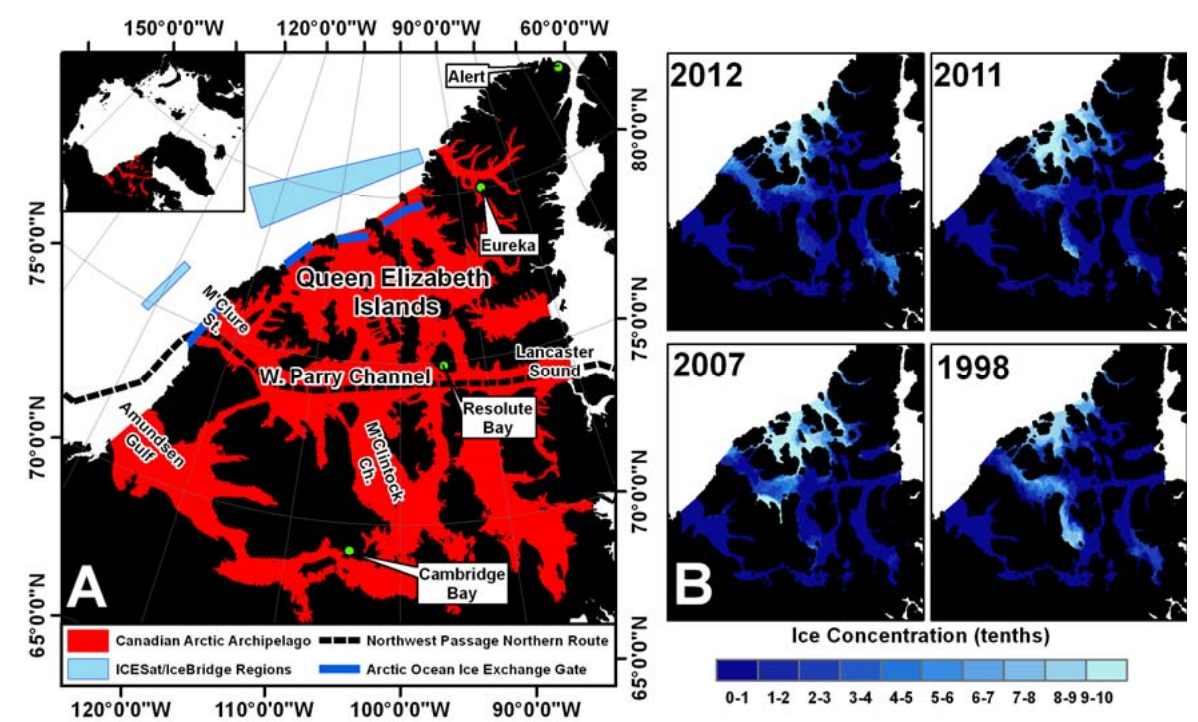

Fig. 1. The geographical location of the Canadian Arctic Archipelago (CAA) (A) and spatial distribution of CAA mean September total ice concentration (tenths) for the four extreme light years $(\mathbf{B})$.

al., 1996), shattering the previous 2007 record. The 2012 September mean value represents $\sim 50 \%$ less sea ice area within the Arctic compared to the 1981-2010 mean September climatology. 2012 sea ice conditions actually fell below the 2007 record in August, following a dramatic storm that tracked across the Arctic from Siberia and into the Canadian Arctic Archipelago (CAA) (Simmonds and Rudeva, 2012). Parkinson and Comiso (2013) found that decades of preconditioned thinning made the sea ice more vulnerable to the 2012 storm. Moreover, Zhang et al. (2013) have argued that the 2012 record low would still have occurred without the storm. The latter results are consistent with the view that Arctic sea ice is now thinner and more vulnerable to anomalous atmospheric forcing compared to previous decades (Stroeve et al., 2011a).

Within the CAA, 2011 was the record lightest sea ice year, with a mean September area of $146 \times 10^{3} \mathrm{~km}^{2}$, but 2012 was a close second at $150 \times 10^{3} \mathrm{~km}^{2}$ (Fig. 1a, b). These values represent $\sim 60 \%$ less sea ice area within the CAA compared to the 1981-2010 mean September climatology. Prior to 2011, the lightest ice year within the CAA occurred in 1998 , with a mean September ice area of $200 \times 10^{3} \mathrm{~km}^{2}$, and 2007 ranked as the second lightest, with a mean September ice area of $220 \times 10^{3} \mathrm{~km}^{2}$ (Fig. 1a, b). Interestingly, the driving processes behind the 1998 and 2007 minima were very different. Atmospheric circulation during the summer months of 1998 allowed predominantly warm southerly air masses to flow over the CAA (Atkinson et al., 2006). The resultant anomalously warm SAT and restriction of Arctic Ocean MYI inflow into the CAA combined to gradually ablate the thicker MYI over a longer than normal melt season (Howell et al., 2010). In 2007, anomalously warm July SAT facilitated an intense and rapid melt which led to light ice conditions in the CAA, but this was partially mitigated by high SLP over the Beaufort Sea which facilitated the inflow of Arctic Ocean MYI into the CAA (Howell et al., 2010). Furthermore, unlike 2007, sea ice in 1998 exhibited no evidence of preconditioned thinning leading up the minimum (Howell et al., 2010). In the years that followed the record light ice year of 1998, the CAA returned to heavier summer ice conditions, but the years that followed 2007 only witnessed a slight increase in end-of-summer ice (apparent in 2008 and 2009; Fig. 2). Perhaps more striking is that five of the lightest ice years in the CAA since 1968 (i.e. 2007, 2008, 2010, 2011 and 2012) have all occurred within the last $6 \mathrm{yr}$ (Fig. 1c). Considering the recent observed extreme light ice years within the CAA, three questions need to be addressed: (i) what were the processes that contributed to the record extreme light ice years of 2011 and 2012?; (ii) how were these processes similar to or different from 1998 and 2007?; and (iii) could the CAA experience a heavy summer ice cover in upcoming years?

In order to answer these questions, this paper investigates the processes contributing to the extreme light years of 2011 and 2012, compares them to those responsible for the previous extreme minima of 1998 and 2007, and contrasts the processes behind extreme light sea ice years with those behind extreme heavy ice years. Understanding the driving processes behind light and heavy summer sea ice conditions within the CAA is important because when global climate models indicate a seasonally sea ice-free Arctic Ocean (i.e. less than 1 million $\mathrm{km}^{2}$ ) they still find sea ice to be present within the CAA (e.g. Holland et al., 2006; Sou and Flato, 2009; Wang and Overland, 2012). Even as climate model resolution continues to improve, resolving sea ice thermodynamic and dynamic processes within the narrow channels 


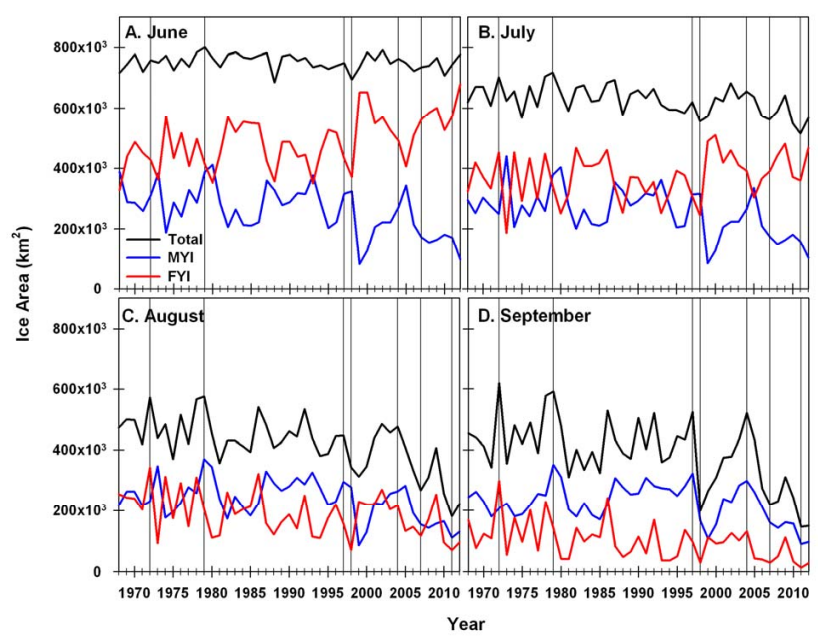

Fig. 2. Time series of mean monthly total ice, multi-year ice (MYI) and first-year ice (FYI) area $\left(\mathrm{km}^{2}\right)$ within the Canadian Arctic Archipelago for June to September (A-D) from 1968-2012. The vertical bars represent the extreme light and heavy years.

of the CAA will still remain difficult. Knowledge of the driving factors behind heavy and light sea ice conditions in the CAA is also of particular importance for Northwest Passage shipping activities (ACIA, 2004; AMSA, 2009).

This paper is organized as follows. Section 2 describes the data and methods used in the analysis. Section 3 defines the framework of the study by looking at the CAA's extreme light and heavy ice years within a historical time series. Section 4 describes the melt season evolution of sea ice cover in the CAA during extreme light and heavy ice years. Section 5 discusses the thermodynamic and dynamic processes during these two types of seasons. Section 6 discusses the role of preconditioned ice thinning on the recent extreme minima. Section 7 discusses the implications for navigating the Northwest Passage given the recent occurrence of more frequent extreme ice minima. Conclusions are presented in Sect. 8.

\section{Data and methods}

\subsection{Canadian Ice Service Digital Archive}

Weekly total, MYI, and FYI concentration (tenths) and area $\left(\mathrm{km}^{2}\right)$ were extracted from the Canadian Ice Service Digital Archive (CISDA) for 1968 to 2012, from June to October for the CAA domain shown in Fig. 1a. The CISDA is a compilation of Canadian Ice Service regional weekly ice charts that integrate all available real-time sea ice information from various satellite sensors, aerial reconnaissance, ship reports, operational model results and the expertise of experienced ice forecasters, spanning 1968 to the present (Canadian Ice Service, 2007). The CISDA ice charts are topologically complete polygon ArcInfo Geographic Infor- mation System coverages and available online from the CIS (http://ice.ec.gc.ca/).

The CISDA is more accurate than Scanning Multichannel Microwave Radiometer (SMMR) and Special Sensor Microwave/Imager (SSM/I) passive microwave ice concentration retrievals during the melt season (Agnew and Howell, 2003). The CISDA contains a technological bias (related to advances in sensor technology and changes in regional focus due to the emergence of important shipping routes; Tivy et al., 2011). The main focus of this study is on processes during light versus heavy ice seasons, not the trends in ice area or concentration, therefore the impact of any technological and methodological changes will exert minimal influence on the results. CISDA monthly averages of total, MYI, and FYI area and concentration were calculated for the melt season months of June to September. The 1981-2010 period was chosen to represent the historical climatology, and standardized anomalies for total, MYI, and FYI were calculated by dividing anomalies by the 1981-2010 climatological standard deviation.

The years of 1972, 1979, 1997 and 2004 were selected as the extreme heavy ice years to compare against the four extreme low years of 1998, 2007, 2011 and 2012. 1972 and 1979 rank as the two years with the heaviest September ice conditions since 1968. 1997 (5th heaviest; Fig. 2) and 2004 (6th heaviest; Fig. 2) were selected instead of 1978 (3rd heaviest; Fig. 2) and 1986 (4th heaviest; Fig. 2) because the source of the CAA's MYI changed from FYI aging to a combination of FYI aging and Arctic Ocean MYI inflow in 1995 (Howell et al., 2009). Selecting heavy ice years in both periods allows for a more representative investigation of the processes behind heavy ice years. Moreover, 1978 and 1986 exhibited an almost identical ice evolution as the 1st and 2nd heaviest ice years, and discussing their evolutions would have been redundant (i.e. the conclusions of the paper would not change).

\subsection{Canadian Arctic Archipelago-Arctic Ocean ice exchange}

Ice exchange between the CAA and the Arctic Ocean during the months of May to September was estimated at the M'Clure Strait and the Queen Elizabeth Islands (QEI) gates (Fig. 1a). While ice exchange does occur between the Amundsen Gulf and the Arctic Ocean, the Amundsen Gulf becomes ice-free during the summer months, and ice exchange provides a negligible source of CAA ice replenishment during the melt season (Kwok, 2006; Agnew et al., 2008; Howell et al., 2008; Canadian Ice Service, 2011).

Ice exchange was derived from sequential RADARSAT1 or RADARSAT- 2 synthetic aperture radar (SAR) imagery with a spatial resolution of $\sim 200 \mathrm{~m} \mathrm{pixel}^{-1}$ using the Canadian Ice Service's Automated Ice Tracking System (CISASITS). For extreme light and heavy years (only the 1997 and 2004 heavy years were within the RADARSAT period) the temporal resolution of the RADARSAT imagery was 
between 2-5 days. A detailed description of the sea ice motion tracking system can be found in Wohlleben et al. (2013) and Komarov and Barber (2013). Here we briefly outline key elements of the ice tracking algorithm. The system operates with two sequential SAR images and derives a detailed map of ice displacements for the time interval separating the images. The algorithm captures both translational and rotational components of ice motion based on a combination of the phase- and cross-correlation matching techniques. To reduce the computation time, several pyramid levels are generated from the original SAR images. At each resolution level various ice features (e.g. cracks, floes, ridges) suitable for tracking are automatically identified. First, the ice motion is derived at the lowest resolution level. Then at each consecutive resolution level the system is guided by the vectors found at the previous resolution level. To eliminate erroneous ice motion vectors, the algorithm compares ice drift vectors derived from the forward pass (tracking from the first image to the second one) and the backward pass (tracking from the second image to the first one). The remaining vectors are further filtered by thresholding their cross-correlation coefficients. Finally, at each resolution level, a high, medium or low level of confidence is assigned to each ice drift vector according to the cross-correlation coefficient value. The accuracy of the algorithm was thoroughly examined based on the visual detection of similar ice features in sequential SAR images and ground truthed with ice-tracking beacon data for various ice conditions. In Komarov and Barber (2013) a very good agreement between the SAR-derived vectors and the trajectories of drifting ice beacons located in close proximity (less than $3 \mathrm{~km}$ ) to the nearest SAR ice motion vectors was observed. The root mean square error (RMSE) was $0.43 \mathrm{~km}$ for 36 comparison points.

Sea ice area flux was estimated using an approach similar to Kwok (2006) and Agnew et al. (2008). Sea ice motion for each image pair was first interpolated to each exchange gate, including a buffer region of $\sim 30 \mathrm{~km}$ on each side of the gate, and then sampled at $5 \mathrm{~km}$ intervals across the gate. Sea ice area flux $(F)$ at each gate was calculated using:

$F=\sum c_{i} u_{i} \Delta x$

where $\Delta x$ is the spacing along the gate $(5 \mathrm{~km}), u_{i}$ is the ice motion normal to the flux gate at the ith location and $c_{i}$ is the sea ice concentration obtained from the CISDA. Assuming the errors of the motion samples are additive, unbiased, uncorrelated and normally distributed, the uncertainty in area flux across the gates $\left(\sigma_{\mathrm{f}}\right)$ can be estimated using:

$\sigma_{\mathrm{f}}=\sigma_{\mathrm{e}} L / \sqrt{N_{\mathrm{s}}}$,

where $\sigma_{\mathrm{e}} \sim 0.43 \mathrm{~km} \mathrm{day}^{-1}$ is the error in SAR-derived ice velocities deduced from Komarov and Barber (2013), $L$ is the width of the gate $(\mathrm{km})$ and $N_{\mathrm{s}}$ is the number of samples across the gate. For the M'Clure Strait and QEI gates, the area flux uncertainty is $\sim 12-14 \mathrm{~km}^{2} \mathrm{day}^{-1}$. For each exchange gate, sea ice flux estimates from all available image pairs were summed over each month for May to September.

\subsection{Ice thickness}

Ice, Cloud, and land Elevation Satellite (ICESat) and IceBridge ice thickness estimates were obtained prior to the melt season to investigate changes in the thickness of Arctic Ocean MYI that would flow into the CAA during the melt season. The ICESat ice thickness estimates are made using satellite-based laser altimetry and are the same used in Kwok et al. (2009) and have an uncertainty of $\sim 0.37 \mathrm{~m}$. A full description of the retrieval methodology can be found in Kwok et al. (2007) and Kwok et al. (2009). IceBridge ice thickness estimates are also made by laser altimetry, but from an airborne platform using the Airborne Topographic Mapper that is fully described in Krabill et al. (2002). IceBridge thickness data were provided by the National Snow and Ice Data Center (Kurtz et al., 2012) using the retrieval methodology described by Kurtz et al. (2013). For each year from 20092012, we selected the closest IceBridge flight line to the Arctic Ocean M'Clure Strait and Arctic Ocean QEI ice exchange gates. The IceBridge flight lines for these gates covered the spatial domains shown in blue in Fig. 1a. The mean ICESat thickness for the same region was extracted from 2004-2008. The dates of the IceBridge flight lines and the ICESat time period is shown in Table 1. The uncertainty of each IceBridge flight line is also shown in Table 1, and Kurtz et al. (2013) state that the evaluation of the accuracy of the data set is ongoing. As a result we exercise caution in the interpretation of thickness estimates.

\subsection{Ancillary data sets}

The date of melt onset and freeze onset from 1979-2012 within the CAA (Fig. 1a) was retrieved from the satellite passive microwave algorithm described by Markus et al. (2009). SLP and SAT data from 1968-2012 were extracted from the National Center for Environmental Prediction-National Center for Atmospheric Research (NCEP-NCAR) Reanalysis (Kalnay et al., 1996; Kistler et al., 2001). Finally, net shortwave $\left(K^{*}\right)$ and net longwave $\left(L^{*}\right)$ data from 1979-2012 were extracted from North American Regional Reanalysis (NARR) (Mesinger et al., 2006). There are large known biases in radiative fluxes over the Arctic in re-analyses products (Walsh et al., 2009), therefore despite only starting in 1979 we used NARR to better capture the ice within narrow channels and inlets of the CAA.

\section{Extreme light and heavy ice years within the historical context}

The monthly time series of June to September total ice and MYI area within the CAA is shown in Fig. 2. Total ice has 
Table 1. ICESat and IceBridge ice thickness estimates within the Canadian Basin just north of the Arctic Ocean-Queen Elizabeth Islands (QEI) and Arctic Ocean-M'Clure Strait ice exchange gates, 2004-2012. IceBridge mean uncertainty in brackets.

\begin{tabular}{rrrll}
\hline Year & $\begin{array}{r}\text { Ice Thickness (m) } \\
\text { QEI }\end{array}$ & $\begin{array}{r}\text { Ice Thickness (m) } \\
\text { M'Clure Strait }\end{array}$ & Sensor & Date \\
\hline 2004 & 5.6 & 3.5 & ICESat & Feb-Mar \\
2005 & 5.6 & 3.6 & ICESat & Feb-Mar \\
2006 & 5.1 & 4.0 & ICESat & Feb-Mar \\
2007 & 5.2 & 2.8 & ICESat & Apr-May \\
2008 & 3.3 & 2.3 & ICESat & Feb-Mar \\
2009 & $3.9(0.7)$ & $2.5(0.8)$ & IceBridge & 2 and 21 Apr \\
2010 & $4.4(0.8)$ & $2.7(0.9)$ & IceBridge & 5 and 21 Apr \\
2011 & $3.7(0.6)$ & N/A & IceBridge & 16 Mar \\
2012 & $3.3(0.8)$ & $1.4(1.1)$ & IceBridge & 19 and 22 Mar \\
\hline \multicolumn{5}{c}{} \\
\hline \multicolumn{5}{c}{}
\end{tabular}

been relatively stable in June and July because much of the sea ice within the CAA remains landfast well into July. In terms of FYI and MYI for June and July, there has been a decrease in MYI and a corresponding increase in FYI, most noticeable since 1998. Over the entire period, both August and September FYI have experienced a slow downward trend, whereas MYI remained steady and only began to drop off after 1998. The September total ice time series points out how strong the 1998 anomaly was, as ice conditions were relatively stable until then. While subsequent minima were low (2007) or lower (2011 and 2012), they are within a context that now favours light years, which was not the case for the 1998 minima.

Standardized anomalies are provided in Table 2 for monthly total, MYI and FYI, for light and heavy ice light years. The heavy ice years tended to experience mostly positive total ice standardized anomalies for June and July. Total ice anomalies for heavy ice years during August and September were all positive. In addition, total, MYI and FYI for 2011 and 2012 in September were lower than 1998 and 2007.

The spatial distribution of mean June and September total ice and MYI for the light ice years is shown in Fig. 3, and for heavy ice years in Fig. 4. In June, negative total ice concentration anomalies for light years were located in peripheral regions of the CAA (e.g. Amundsen Gulf, M'Clure Strait and Lancaster Sound where melt had already begun). Negative MYI concentration anomalies in June were more widespread throughout the CAA (with the exception of positive MYI anomalies across the southern CAA in 1998; see Table 2), especially in 2012. June MYI concentrations for the extreme heavy ice years exhibited positive anomalies throughout most of the CAA.

In September, negative total ice concentration anomalies were located primarily within the QEI, western Parry Channel and M'Clintock Channel. The negative total ice anomalies were particularly strong and widespread in 2011 and 2012. The western Parry Channel and M'Clintock Channel were almost $100 \%$ ice-covered during the heavy ice years, which may suggest that these regions are more sensitive

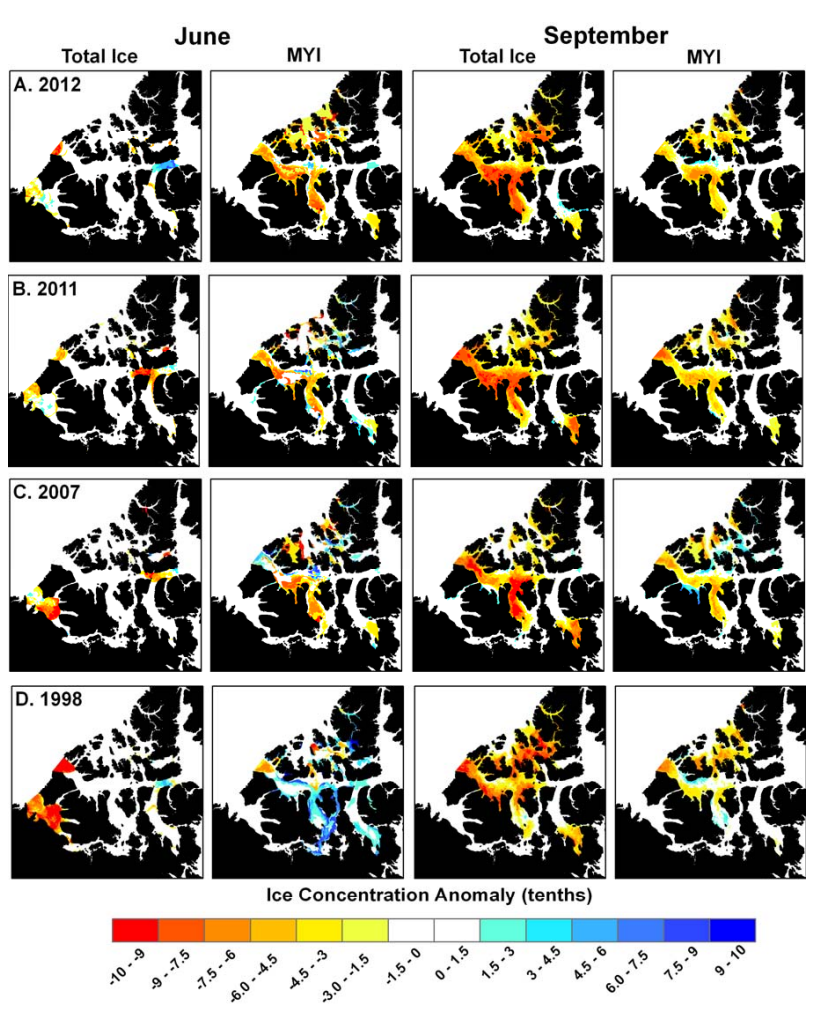

Fig. 3. Spatial distribution of June and September total ice and multi-year ice (MYI) concentration anomalies (tenths) for the light ice years of 2012, 2011, 2007 and 1998 within the Canadian Arctic Archipelago (A-D). Anomalies calculated with respect to the 1981-2010 climatology.

to anomalous thermodynamic atmospheric forcing events which produce light ice years. The light ice years contained virtually no strong positive MYI concentration anomalies in September. For heavy ice years, only 1972 experienced negative MYI concentration anomalies in the western Parry Channel and M'Clintock Channel. With no coincident total ice concentration negative anomalies evident during that year, 
Table 2. Monthly June to September total, multi-year ice (MYI) and first-year ice (FYI) standardized anomalies for extreme light and heavy sea ice years in the Canadian Arctic Archipelago. The top rows are light ice years and the bottom rows are heavy ice years. Standardized anomalies calculated with respect to the 1981-2010 climatology.

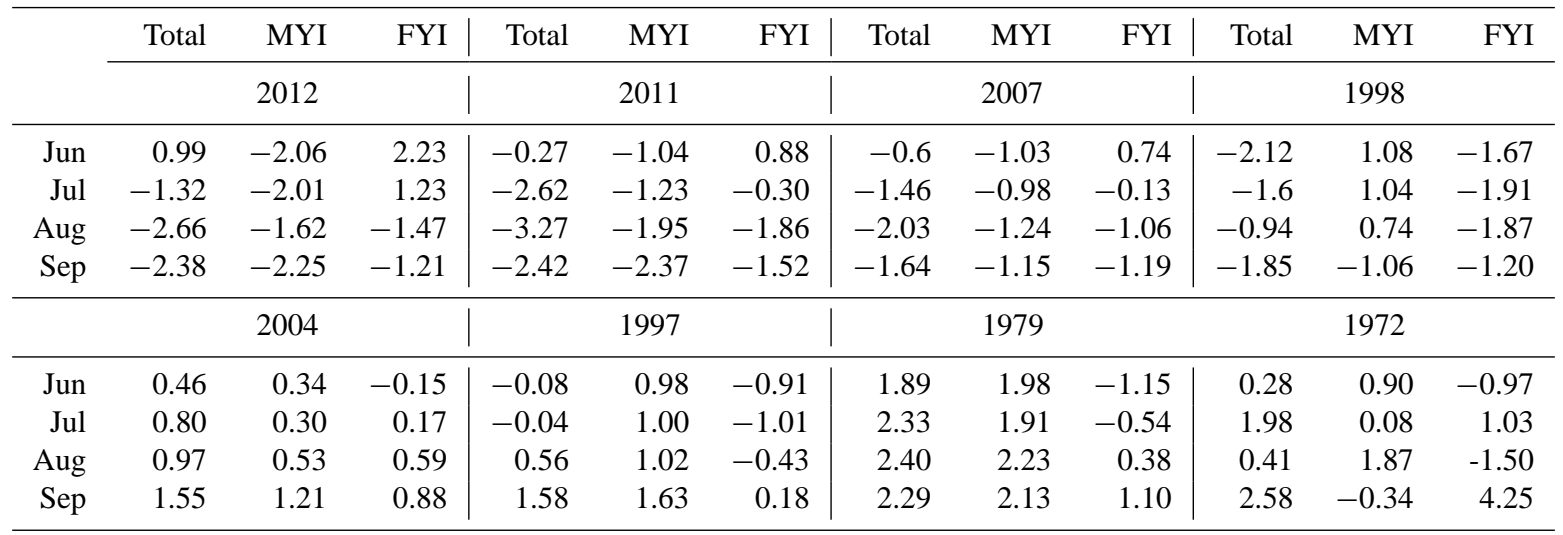
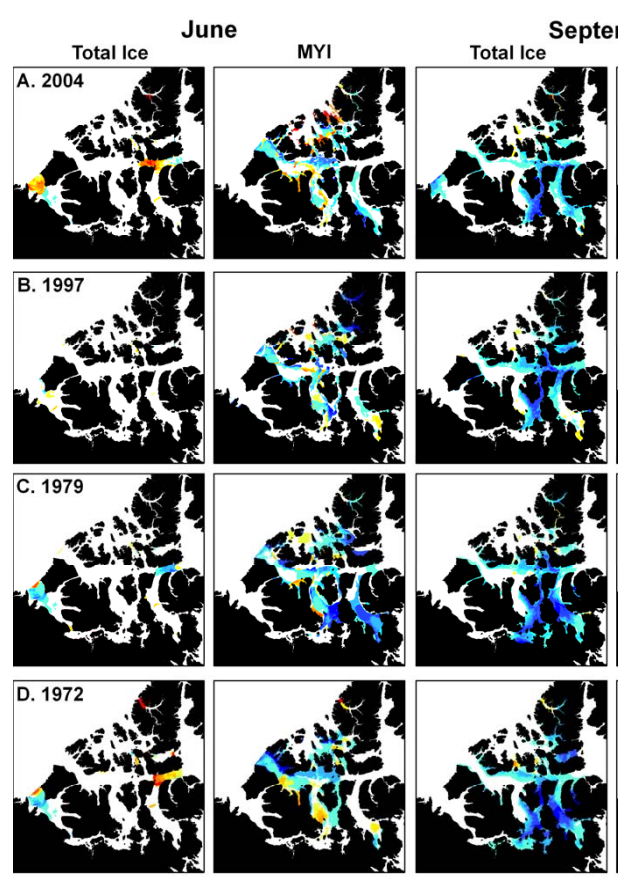

Ice Concentration Anomaly (tenths)

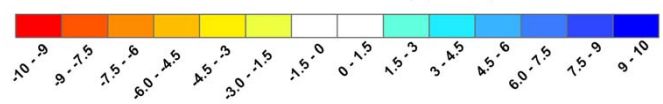

Fig. 4. Spatial distribution of June and September total ice and multi-year ice (MYI) concentration anomalies (tenths) for the heavy ice years of 2004, 1997, 1979 and 1972 within the Canadian Arctic Archipelago (A-D). Anomalies calculated with respect to the 1981-2010 climatology.

this suggests that FYI survived the melt season in these regions, a conclusion further supported by 1972 having the highest mean September FYI area on record $\left(298 \times 10^{3} \mathrm{~km}^{2}\right.$; Fig. 2d).
Over the $45 \mathrm{yr}$ record of sea ice conditions within the CAA, 2011 and 2012 both stand out as extreme light ice years, even more so than 1998 and 2007, in which the previous record minima were observed. Regionally, this was particularly apparent within the western Parry Channel and M'Clintock Channel (Fig. 3). Although FYI melts more easily because it is thinner than MYI, which in turn is more likely to facilitate light ice conditions under anomalous atmospheric forcing, it is important to note that the earlier breakup of thinner FYI increases the opportunity of MYI inflow from the Arctic Ocean. This process was shown to reduce total ice loss over the melt season (Howell et al., 2008, 2009). In order to investigate the driving processes that contributed to the new record low years of 2011 and 2012, and comment on the processes required for the CAA to experience a heavy ice year, we first investigate the melt seasonal sea ice area progression during both light and heavy ice years.

\section{Melt season progression of Canadian Arctic Archipelago sea ice cover}

\subsection{Light years}

The time series of weekly total ice, MYI and FYI for the extreme light ice years 1998, 2007, 2011 and 2012 is shown in Fig. 5. Total ice for the record low year of 2011 initially tracked higher than that of the previous record low year of 1998 until early July, when the rate of ice loss increased and eventually reached a record minimum of $97 \times 10^{3} \mathrm{~km}^{2}$ on 5 September. The 2011 minimum was considerably lower than observed in $1998\left(133 \times 10^{3} \mathrm{~km}^{2}\right.$ during the week of 28 September) and $2007\left(175 \times 10^{3} \mathrm{~km}^{2}\right.$ during the week of 10 September). Total ice for 2012 tracked above previous extreme light years and the 1981-2010 climatological mean until mid-July, when it experienced a very rapid rate of decline and reached the second lowest minimum in the observational 


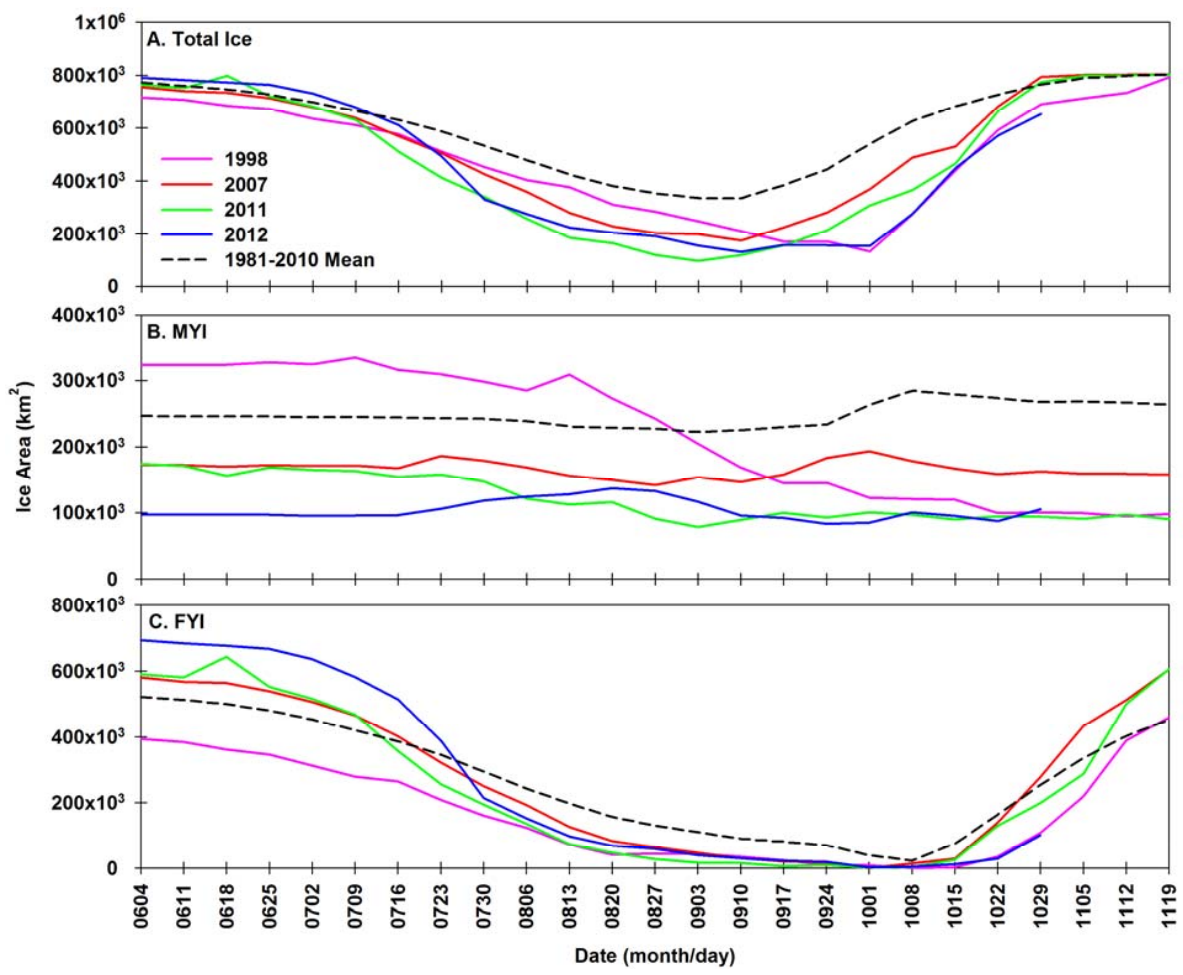

Fig. 5. Weekly time series of total ice (A), multi-year (MYI) (B) and first-year ice (FYI) (C) area $\left(\mathrm{km}^{2}\right)$ for 1998, 2007, 2011 and 2012 in the Canadian Arctic Archipelago.

record of $131 \times 10^{3} \mathrm{~km}^{2}$ during the week of 10 September. Howell et al. (2010) characterized the 2007 ice loss as relatively rapid when compared against the gradual loss of 1998 . However, the total ice time series in Fig. 5a shows that both 2011 and 2012 experienced an even more rapid rate of decline than 2007.

The time series of FYI (Fig. 5c) also highlights the gradual decline in 1998, the rapid decline in 2007 and even more rapid decline during 2011 and 2012. In addition, virtually all FYI melted during the light ice years. The time series of MYI (Fig. 5b) indicates that both 1998 and 2011 exhibited almost no MYI increases during the melt season, indicating reduced inflow from the Arctic Ocean. 2007 and 2012 did, however, experience MYI increases during August and September, indicating the inflow of MYI to the CAA from the Arctic Ocean.

In summary, in all four light ice seasons virtually all the FYI melted by the end of the summer. The rate of ice loss was relatively slow and persistent in 1998, while the rapid rate of decline in 2007 was exceeded in 2011 and 2012. MYI increases due to import from the Arctic Ocean mitigated the melt season ice loss in 2007 and 2012, while the lack of MYI import during the 1998 and 2011 melt seasons contributed to the record low ice minima set during those seasons.

\subsection{Heavy years}

The weekly time series of total ice, MYI and FYI for 1972, 1979, 1997 and 2004 are shown in Fig. 6. Both 1972 and 1979 exhibited a similar slow rate of total ice decline, reaching minima of $533 \times 10^{3} \mathrm{~km}^{2}$ on 28 August and $535 \times 10^{3} \mathrm{~km}^{2}$ on 6 September, respectively. 1997 and 2004 experienced a greater rate of decline compared to 1972 and 1979 and reached minima of $426 \times 10^{3} \mathrm{~km}^{2}$ on 28 August and $431 \times 10^{3} \mathrm{~km}^{2}$ on 6 September, respectively. The extreme heavy ice year minima, on average, represent $\sim 80 \%$ more ice area compared to the record light minimum of 2011.

The FYI and MYI time series (Fig. 6b, c) for the heavy ice years highlight the two processes associated with heavier ice-covered summers within the CAA: FYI aging and Arctic Ocean MYI import. 1 October is the date each year on which any FYI remaining at the end of the melt season is promoted to MYI (i.e. FYI aging). Although the rate of FYI loss during 1997 and 2004 was greater than in 1972 and 1979, it was still considerably less than the FYI loss during the extreme light years (Figs. 5c and 6c). All four heavy ice seasons show a rapid increase in MYI after 1 October, ranging from $\sim 75 \times 10^{3} \mathrm{~km}^{2}$ for 1997 to $\sim 250 \times 10^{3} \mathrm{~km}^{2}$ for 1972 . The latter values provide an approximate estimate of the amount of FYI that has survived the melt season and that was promoted to MYI. This process was almost completely absent during the extreme light ice years because of the lack of FYI 


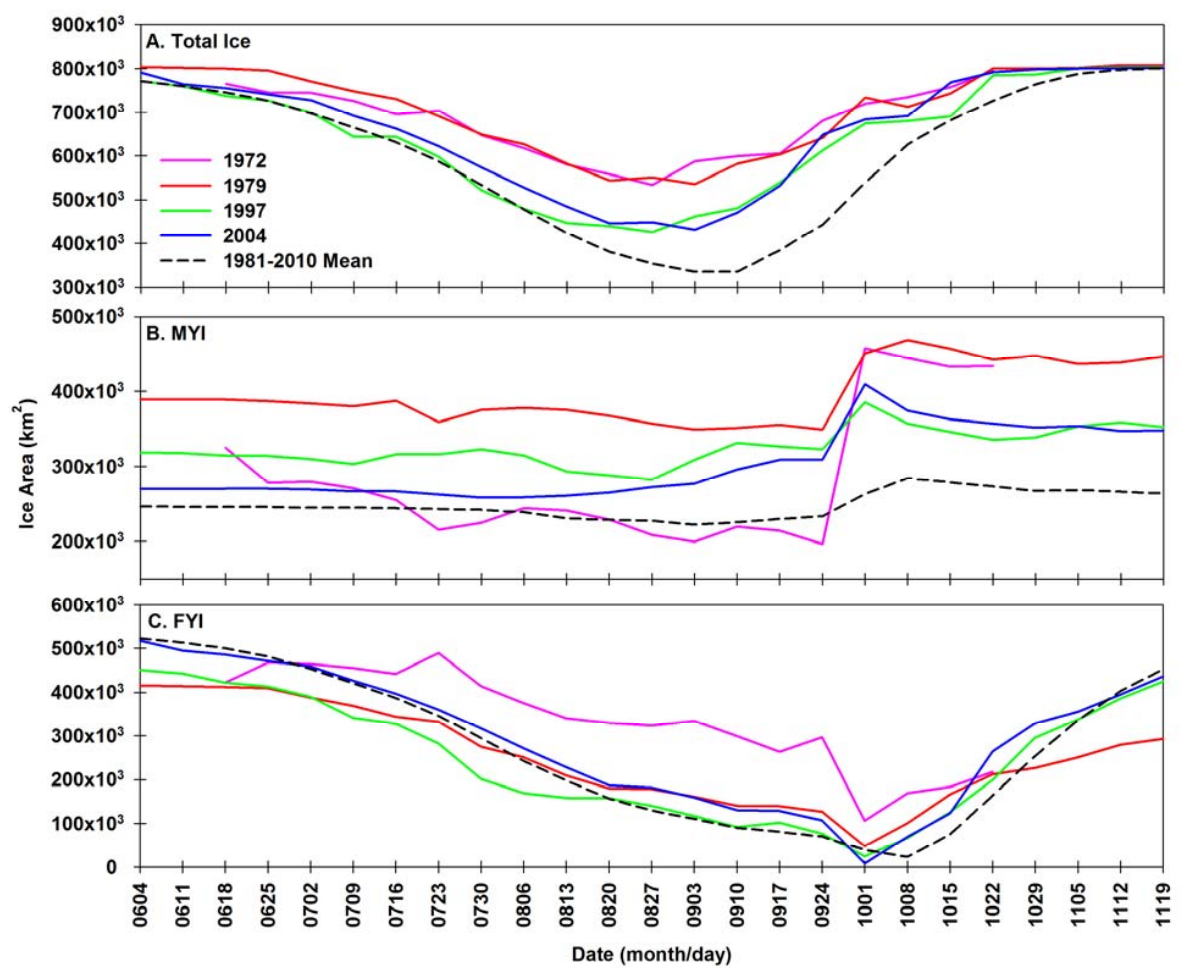

Fig. 6. Weekly time series of total ice (A), multi-year (MYI) (B) and first-year ice (FYI) (C) areas $\left(\mathrm{km}^{2}\right)$ for 1972, 1979,1997 and 2004 in the Canadian Arctic Archipelago.

at the end of the melt season (Fig. 5c). The role of MYI import during heavy ice years was evident by comparing 1972 and 1979 with 1997 and 2004. Although the increase in MYI on 1 October for 1997 and 2004 was small when compared to 1972 and 1979, there was also a net increase in MYI from 4 June to 24 September that can be attributed to Arctic Ocean inflow.

In summary, 1972 and 1979 experienced a large end-ofseason MYI increase from FYI aging, while both 1997 and 2004 experienced an MYI increase from a combination of FYI aging and Arctic Ocean MYI inflow. In order to explain these differences in the seasonal evolution of summer ice cover for both light and heavy years, we now look at the driving thermodynamic and dynamic processes.

\section{Thermodynamic and dynamic processes behind extreme ice years}

\subsection{Light years}

The dominant JJAS atmospheric circulation pattern during the extreme light years consisted of high SLP anomalies over Greenland and the Beaufort Sea (Fig. 7). This atmospheric circulation pattern transports warm air into the CAA, which influences the role of SAT in sea ice melt and also promotes clearer skies, which influences the role of shortwave radiative forcing in sea ice melt. With respect to SAT, the time series of JJAS anomalies shows positive departures for all extreme light years, with the 2012 anomaly of $2.28^{\circ} \mathrm{C}$ exceeding the previous record anomaly of $2.0^{\circ} \mathrm{C}$ set in 1998 (Fig. 8). 1998 has long been recognized as one of the warmest years in the Canadian Arctic, which exerted a strong influence on CAA sea ice conditions along with other elements of the Canadian cryosphere (e.g. Jeffers et al., 2001; Alt et al., 2006; Atkinson et al., 2006; Howell et al., 2010). The JJAS SAT anomaly for the record low ice year of 2011 ranked third at $1.80^{\circ} \mathrm{C}$, while 2007 was the "coolest" of the extreme light years, with an anomaly of $0.71{ }^{\circ} \mathrm{C}$ (Fig. 8). With respect to radiative forcing, the time series of JJAS anomalies of $K^{*}, L^{*}$ and net allwave radiation $\left(Q^{*}\right)$ show strong positive $K^{*}$ departures for all extreme light years (Fig. 9). Of the 4 lightest ice years, 2007 and 2011 had the strongest positive $K^{*}$ anomalies, at $23 \mathrm{Wm}^{-2}$ and $22 \mathrm{Wm}^{-2}$, respectively (Fig. 9). 2012 ranked third with a positive $K^{*}$ anomaly of $16 \mathrm{Wm}^{-2}$, and $1998 \mathrm{ex}-$ perienced the lowest $K^{*}$ anomaly of the extreme light years, at $9 \mathrm{Wm}^{-2}$ (Fig. 9). $L^{*}$ anomalies for the extreme years were negative (i.e. 1998, 2007, and 2011) or just slightly positive (i.e. 2012) (Fig. 9).

The new record extreme light ice years of 2011 and 2012 are associated with positive JJAS SAT and $K^{*}$ anomalies that in turn helped drive the rapid melt events that began in July. However, the timing of melt onset is also another important factor to consider with respect to thermodynamic forcing on 


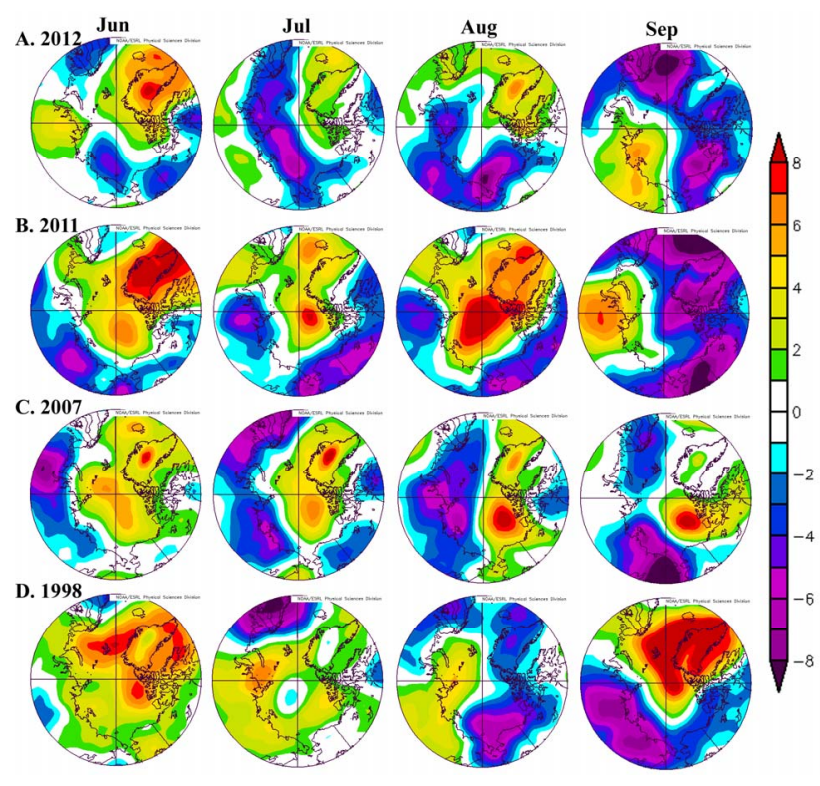

Fig. 7. Spatial distribution of NCEP/NCAR mean June to September sea level pressure (SLP; mb) anomalies for 2012, 2011, 2007 and 1998 (A-D). Anomalies calculated with respect to the 19812010 climatology.

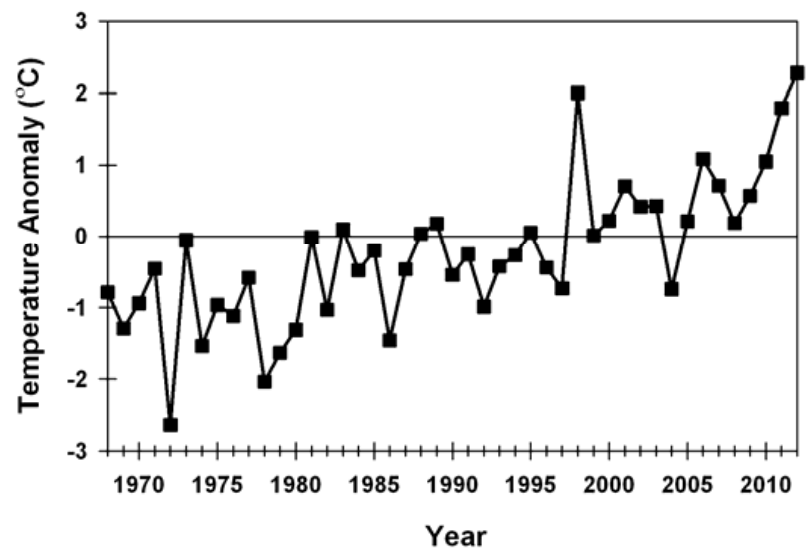

Fig. 8. Time series of NCEP/NCAR mean June through September (JJAS) surface air temperature (SAT) anomalies $\left({ }^{\circ} \mathrm{C}\right)$ in the Canadian Arctic Archipelago, 1968-2012. Anomalies calculated with respect to the 1981-2010 climatology.

sea ice minima. Perovich et al. (2007) demonstrated that the melt process is enhanced from an earlier melt onset by increasing the energy available for melt during the melt season, and this increased energy can exert an influence on the minimum sea ice area reached over the season. The melt onset dates for 2011 and 2012 were not anomalously early (Fig. 10) and total ice conditions remained near the 1981-2010 climatology in June (Fig. 5a). However, once melt onset began in 2011 and 2012, the sea ice-albedo feedback intensified due to strong positive SAT and $K^{*}$ anomalies and facilitated

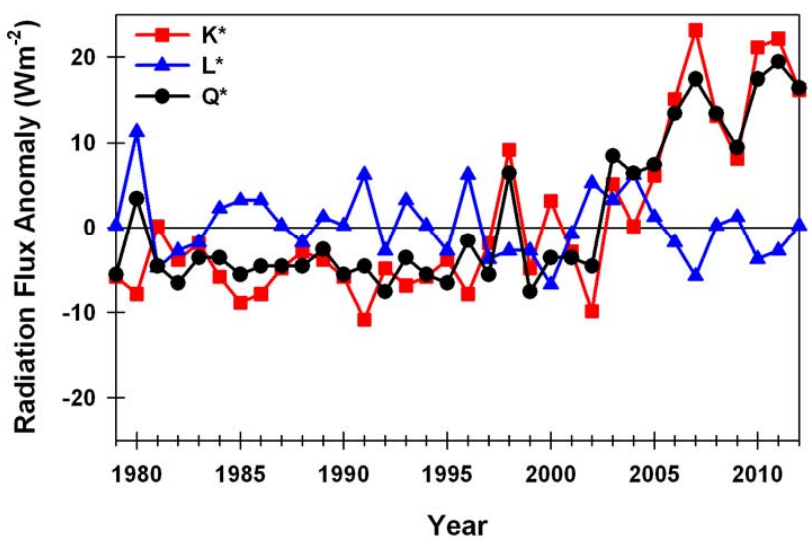

Fig. 9. Time series of NARR mean June through September (JJAS) net shortwave $\left(K^{*}\right)$, net longwave $\left(L^{*}\right)$ and net all-wave $\left(Q^{*}\right)$ radiation anomalies $\left(\mathrm{W} \mathrm{m}^{-2}\right)$ in the Canadian Arctic Archipelago, 1979-2012. Anomalies calculated with respect to the 1981-2010 climatology.

rapid melt. The previous second lightest ice year of 2007 had a similar melt onset date compared to 2011 and 2012 (Fig. 10) and also experienced a rapid melt event, but was less pronounced (Fig. 5a). $K^{*}$ anomalies in 2007 were stronger than both 2011 and 2012, but SAT's were cooler, which suggests that rapid melt in 2007 was potentially influenced more by solar radiation absorption. The melt season length for the previous record lightest ice year of 1998 was long, with melt onset and freeze onset anomalies of -6 days and 14 days, respectively (Fig. 10). The early melt onset in 1998 was important, as it facilitated more total ice loss early in the melt season, thus increasing the energy available for melt that in turn contributed to the gradual melt of ice throughout the remainder of the melt season (Fig. 5a). Comparing 1998 to both 2011 and 2012 indicates similar positive SAT anomalies, but $K^{*}$ anomalies were much lower in 1998, suggesting that SAT played more of a role with respect to ice loss. Atkinson et al. (2006) also suggested that anomalous SAT contributed to the sea ice reductions within the CAA during 1998.

Investigation of the corresponding dynamic processes indicated that in addition to rapid melt, the extreme minimum of 2011 was also driven by July and August atmospheric circulation restricted inflow of ice from the Arctic Ocean. Ice area flux estimates for 2011 show almost net zero exchange between the Arctic Ocean and QEI gates from May to August and a large net inflow of $\sim 21 \times 10^{3} \mathrm{~km}^{2}$ in September (Fig. 11a). Ice area flux estimates indicate almost zero net exchange across the M'Clure Strait gate from May to September for 2011 (Fig. 11b). The weekly MYI time series for 2011 exhibited a gradual decline from June until the first week of September (Fig. 5b), which provides further evidence that very little Arctic Ocean ice exchange occurred. Positive June to August SLP anomalies over the central Arctic Ocean and Greenland in 2011 (Fig. 7b) contributed to reduced exchange 


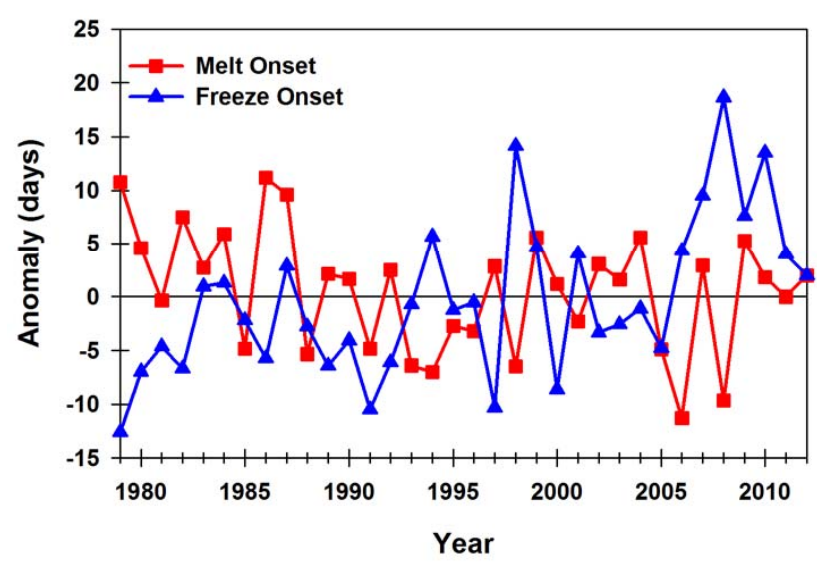

Fig. 10. Time series of the melt and freeze onset anomalies (days) in the Canadian Arctic Archipelago, 1979-2012. Anomalies calculated with respect to the 1981-2010 climatology.

between the Arctic Ocean and CAA, leading up the minimum by facilitating stagnant ice motion within the CAA. Arctic Ocean MYI import via the QEI in September 2011 was caused by a shift in atmospheric circulation that occurred in September (Fig. 7b). MYI for 2011 also began to increase the week after the minimum was reached (Fig. 5b). Similar to 2011, 1998 also experienced reduced Arctic Ocean ice inflow, although June to September SLP anomalies were different (cf. Fig. 7b, d), with atmospheric circulation driving more ice outflow from the CAA into the Arctic Ocean at both the M'Clure and QEI gates in September 1998 (Fig. 11).

With respect to sea ice dynamic forcing for 2012, the minimum was initially driven by rapid melt, but this ice loss was mitigated by Arctic Ocean MYI inflow. The majority of this inflow occurred via the M'Clure Strait in August (Fig. 11b), with MYI during August also exhibiting increases (Fig. 5b). The ice inflow is likely associated with the anomalously low SLP that tracked across the Arctic Ocean and into the CAA (Simmonds and Rudeva, 2012). Following the August ice inflow event, almost zero net ice area flux occurred in September at the M'Clure Strait, but a small net inflow occurred into the QEI (Fig. 11). These Arctic Ocean ice inflow events reduced the CAA's rate of total ice decline, preventing total ice conditions from eclipsing the 2011 record low. This driving dynamic process observed in 2012 was similar to 2007. Although June to September SLP anomalies were different between 2012 and 2007 (Fig. 7a, c), both atmospheric circulation patterns facilitated Arctic Ocean inflow into the CAA. It should be noted however that the 2012 Arctic Ocean ice influx into the M'Clure Strait was driven by 2 single SLP driving events in August (not shown) that are lost in the August monthly SLP average. The key difference between 2012 and 2007 was that despite the net Arctic Ocean ice inflow at the M'Clure Strait in August and at QEI in September for 2012, MYI conditions did not remain high through the remainder

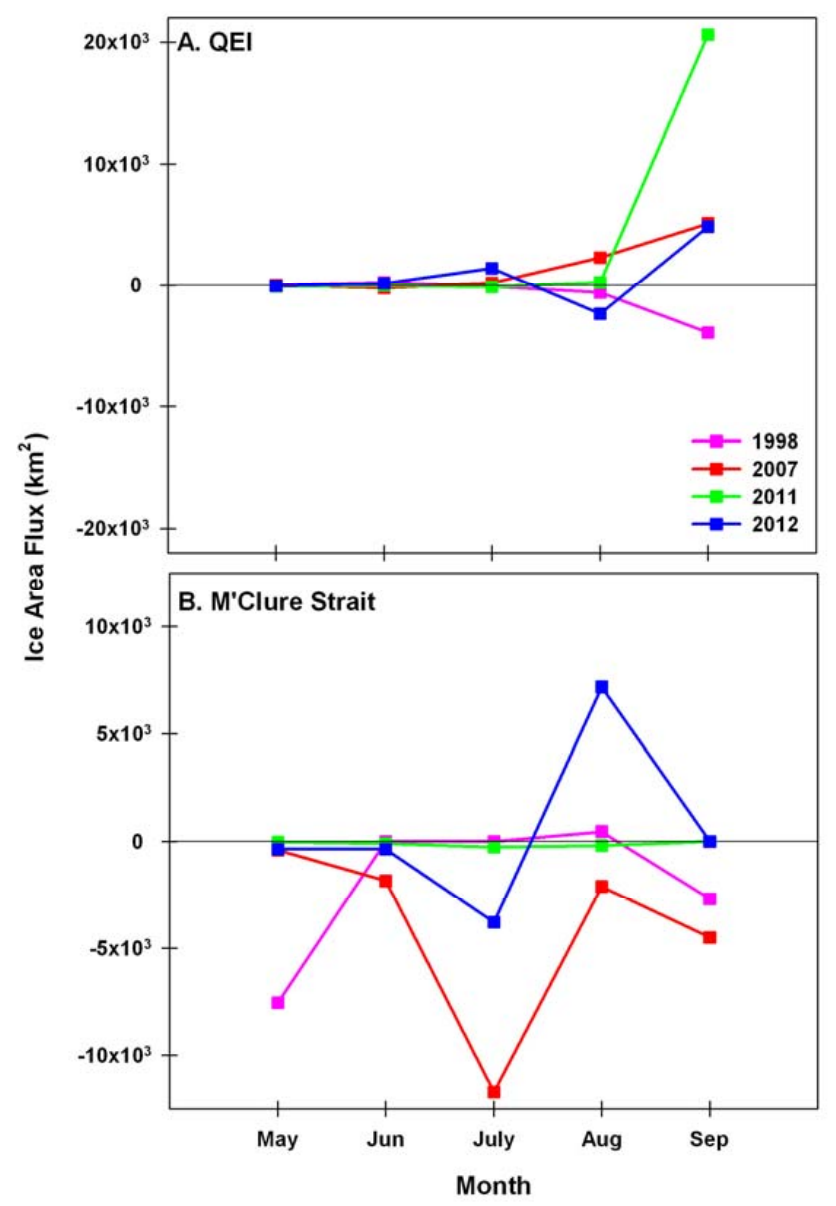

Fig. 11. Time series of mean May to September Arctic OceanCanadian Arctic Archipelago sea ice area flux $\left(\mathrm{km}^{2}\right)$ at the Queen Elizabeth Islands (QEI) (A) and the M'Clure Strait (B) for 1998, 2007, 2011 and 2012, estimated from RADARSAT. Positive/negative sign indicates Arctic Ocean inflow/outflow.

of the 2012 melt season (i.e. the imported MYI subsequently melted; Fig. 5b).

Ice amounts in the CAA for the new record low years of 2011 and 2012 were not driven by the same combination of thermodynamic and dynamic driving processes as 1998 or 2007 , but instead shared processes related to both. While pronounced melt events, either rapid (i.e. 2007, 2011 and 2012) or of long duration (i.e. 1998) are a necessary condition for extreme low ice seasons within the CAA, dynamics also play an important role. Specifically, dynamics can enhance the extreme minima by restricting ice inflow (i.e. 1998 and 2011), amplify the extreme minima by facilitating ice outflow (i.e. 1998), or prevent record-breaking minima by facilitating ice inflow (e.g. 2007 and 2012). 


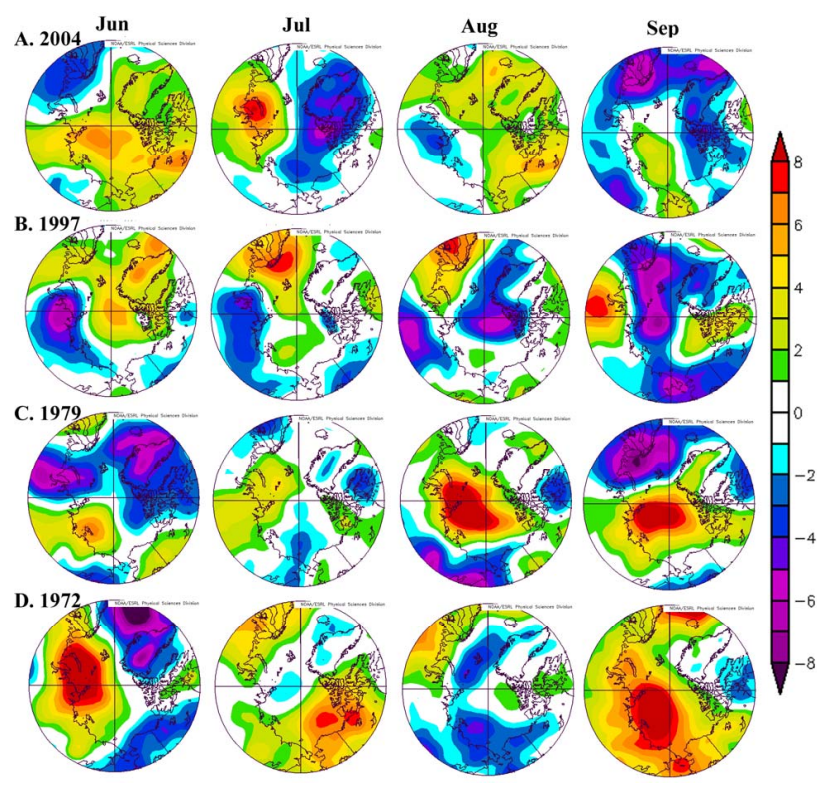

Fig. 12. Spatial distribution of NCEP/NCAR mean June to September (JJAS) sea level pressure (SLP; mb) anomalies for 2004, 1997, 1979 and 1972 (A-D). Anomalies calculated with respect to the 1981-2010 climatology.

\subsection{Heavy years}

The dominant JJAS atmospheric circulation pattern for extreme years was high SLP anomalies over the Laptev and East Siberian seas and low SLP anomalies over Greenland, facilitating cooler conditions over the CAA (Fig. 12), but there was more monthly variability compared to extreme light years (Fig. 7). JJAS SAT anomalies indicate that negative anomalies were present for all the extreme heavy ice years, with 1972 experiencing the strongest negative anomaly of $-2.63^{\circ} \mathrm{C}$ (Fig. 8). $K^{*}$ anomalies were negative for $1979\left(-5.8 \mathrm{Wm}^{-2}\right), 1997\left(-1.8 \mathrm{Wm}^{-2}\right)$ and 2004 $\left(0.2 \mathrm{Wm}^{-2}\right)$, and $L^{*}$ anomalies were only negative for 1997 $\left(3.7 \mathrm{Wm}^{-2}\right)$. The only year that experienced a positive net all-wave radiation balance was 2004 (Fig. 9).

The two heaviest ice years of 1972 and 1979 were likely driven by thermodynamics alone, despite no direct estimates of Arctic Ocean-CAA ice exchange being available. We can eliminate Arctic Ocean ice inflow based on several reasons. The time series of MYI for these years shows very little change prior to the 1 October promotion of FYI, suggesting negligible Arctic Ocean-CAA ice exchange (Fig. 6b). The considerable jump in the MYI weekly time series on 1 October is evidence of significant melt season FYI survival, as opposed to Arctic Ocean ice advection (Fig. 6c). SLP anomalies during August and September for 1979 and during September 1972 indicate atmospheric circulation (i.e. north/northwesterly winds), which would favour Arctic Ocean ice inflow into the CAA (Fig. 12c, d), but the actual ice area flux was negligible because the CAA was already heavily congested with ice throughout the season, which prevented appreciable ice exchange (Fig. 4a, b). Satellitederived melt and freeze onset were not available for 1972, but for 1979 melt onset occurred late and freeze onset early (i.e. short melt season) (Fig. 10). Both $K^{*}$ and $Q^{*}$ experienced strong negative anomalies during 1979 (Fig. 9), and although radiative forcing data was not available for 1972, high SLP anomalies did not persist over the CAA (Fig. 12d), and it was likely that $K^{*}$ anomalies were negative. The cooler temperatures, negative radiation balance and short melt seasons helped reduce melt during 1972 and 1979, resulting in more ice survival, as evident from Fig. 6, and in heavy ice years.

For the heavy ice years of 1997 and 2004, the weaker SAT, $K^{*}$ and melt onset anomalies in 1997 and 2004 (compared to 1972 and 1979) allowed for more summer melt and decreased survival of the FYI. However, the greater areas of open water in these years facilitated Arctic Ocean MYI inflow, which compensated for the slightly increased ice loss from melt. Consider: JJAS SAT anomalies for 1997 and 2004 were slightly negative at $-0.73{ }^{\circ} \mathrm{C}$ and $-0.74{ }^{\circ} \mathrm{C}$, respectively (Fig. 8). $K^{*}$ anomalies were slightly negative for 1997 and slightly positive for 2004 (Fig. 9). Melt onset anomalies for 1997 and 2004 were near normal at 2.7 days and 5.4 days (Fig. 10), and freeze onset anomalies for 2004 were also near normal ( -1 days), but for 1997 they were considerably late at -10 days (Fig. 9). Arctic Ocean MYI inflow occurred at the M'Clure Strait during August and September in 1997 and 2004 and at the QEI in September 2004 (Fig. 13; no RADARSAT imagery available for the QEI in September 1997). August and September SLP anomalies are consistent with these import processes (Fig. 12a, b), and the weekly time series of MYI also illustrates a net increase in MYI prior to 1 October for both 1997 and 2004 (Fig. 6b). Therefore, heavy ice conditions in 1997 and 2004 were driven by a combination of thermodynamic (reduced FYI melt) and dynamic (increased MYI import) forcing.

The CAA's extreme heavy ice years were either driven by thermodynamics alone (i.e. 1972 and 1979) or in concert with dynamics (i.e. 1997 and 2004). There is interplay between thermodynamics and dynamics during heavy ice years, whereby some in situ melt of FYI creates conditions within the CAA which are receptive to atmospherically driven ice inflow from the Arctic Ocean due to some open water fraction. During light ice seasons, extreme ice minima are generally not the result of thermodynamics alone, but are also influenced by dynamic processes (i.e. MYI exchange between the Arctic Ocean and CAA).

\section{Evidence of recent preconditioned thinning}

Howell et al. (2010) found no evidence of preconditioned thinning in the years leading up to 1998 , but noted that 


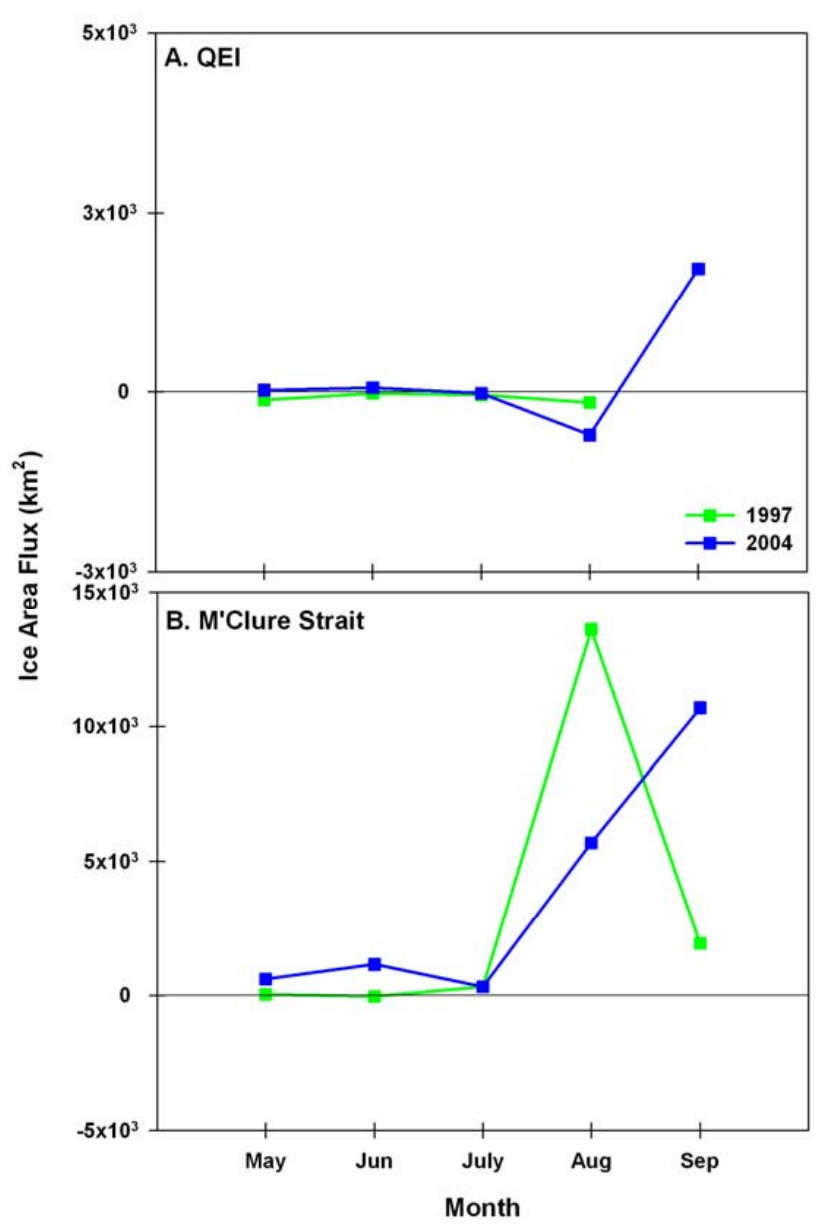

Fig. 13. Time series of mean May to September Arctic OceanCanadian Arctic Archipelago sea ice area flux $\left(\mathrm{km}^{2}\right)$ at the Queen Elizabeth Islands (QEI) (A) and the M'Clure Strait (B) for 1997 and 2004, estimated from RADARSAT. No RADARSAT data were available in September 1997 at the QEI. Positive/negative sign indicates Arctic Ocean inflow/outflow.

preconditioning was apparent prior to 2007 , based on light ice conditions in 2006. Both 2011 and 2012 were able to eclipse these previous extreme light ice years because of stronger preconditioning. Consider that since 1968, the CAA has always experienced a period of recovery following a light ice year, with previous studies indicating that the recovery process can take between 2 and $5 \mathrm{yr}$ (e.g. Melling, 2002; Alt et al., 2006; Atkinson et al., 2006; Howell et al., 2008). For example, following the extreme light ice year of 1998, mean September total ice gradually returned to heavier ice amounts (Fig. 2). However, following the extreme light year of 2007, there was only a brief and small period of recovery in 2008 and 2009, after which ice conditions began to decline again (Fig. 2). The June time series of FYI and MYI exhibit divergent trajectories from 1968 to 2012 (increasing FYI; decreasing MYI), indicating an increased proportion of FYI in the CAA at the start of the melt season (Fig. 2a). Solar ra- diation absorption and transmittance through FYI is larger than MYI because it is thinner, and this results in enhanced ice melt (e.g. Nicolaus et al., 2012; Hudson et al., 2013). The melt seasons of 2011 and 2012 began with June FYI fractions making up $77 \%$ and $88 \%$ of the CAA's total ice component, respectively, compared to $55 \%$ in 1998 (Fig. 2a). As a result of this increased percentage of FYI at the start of the melt season in 2011 and 2012, the majority of the ice in the CAA was more vulnerable to the anomalous thermodynamic forcing (Fig. 8; Fig. 9) that facilitated rapid melt (Fig. 5).

The FYI fraction in 2007 also made up $77 \%$ of the CAA's total ice component, which poses the question: why was preconditioning more apparent in 2011 and 2012? We suggest two possible processes responsible for stronger preconditioning in 2011 and 2012. The first process is the result of recent changes in Arctic Ocean-CAA ice exchange. Howell et al. (2013) found that net MYI inflow from the Arctic Ocean into the CAA via the M'Clure Strait and QEI from May through September (i.e. leading up to minimum sea ice conditions) has decreased considerably since 2007. Specifically, for three years leading up to 2007 (i.e. 2004-2006) the net Arctic Ocean MYI flux was $61 \times 10^{3} \mathrm{~km}^{2}$, but for the three years leading up to 2011 (i.e. 2008-2010) the MYI flux was only $14 \times 10^{3} \mathrm{~km}^{2}$, or $75 \%$ less. Less MYI inflow from the Arctic Ocean into CAA since 2007 has likely contributed to the increased amount of FYI within the CAA and subsequently reduced the CAA's ability to recover MYI leading up to 2011 and 2012.

The second process is that Arctic Ocean MYI flowing into the CAA in 2011 and 2012 may now be less resistant to in situ melt from anomalous thermodynamic forcing because it is thinner. For example, a large inflow of ice from the Arctic Ocean into the CAA via the M'Clure Strait occurred in August 2012 (Fig. 11b), but most of this ice did not survive the melt season (Fig. 5b). ICESat and IceBridge ice thickness estimates near the M'Clure Strait indicate that the ice was thinner at the onset of the 2012 melt season compared to 2004-2006 values (Table 1; Fig. 14). Recently, large amounts of Arctic Ocean MYI circulating from the Canadian Basin to the Eurasian Arctic have melted out in the vicinity of the Beaufort Sea (e.g. Kwok and Cunningham, 2010; Stroeve et al., 2011b), which supports this suggestion that thinner Arctic Ocean MYI (Fig. 14) is unable to survive the melt season.

Additional evidence for thinner Arctic Ocean MYI flowing into the CAA is also apparent looking at the weekly time series of MYI in 2007 that shows an increase from August to September (Fig. 5b). The latter increases were primarily from the QEI (Fig. 11b), and the majority of this MYI was able to survive the melt season, as evident from the lack of decreases leading up to 1 October 2007 (Fig. 5b). Ice area ice flux estimates into the CAA via the QEI in 2011 and 2012 were greater than and similar to 2007, respectively (Fig. 11a), yet less MYI survived the melt season (Fig. 5b). Ice thickness values have decreased near the QEI exchange gates following the 2007 melt season and are thinner when compared to 


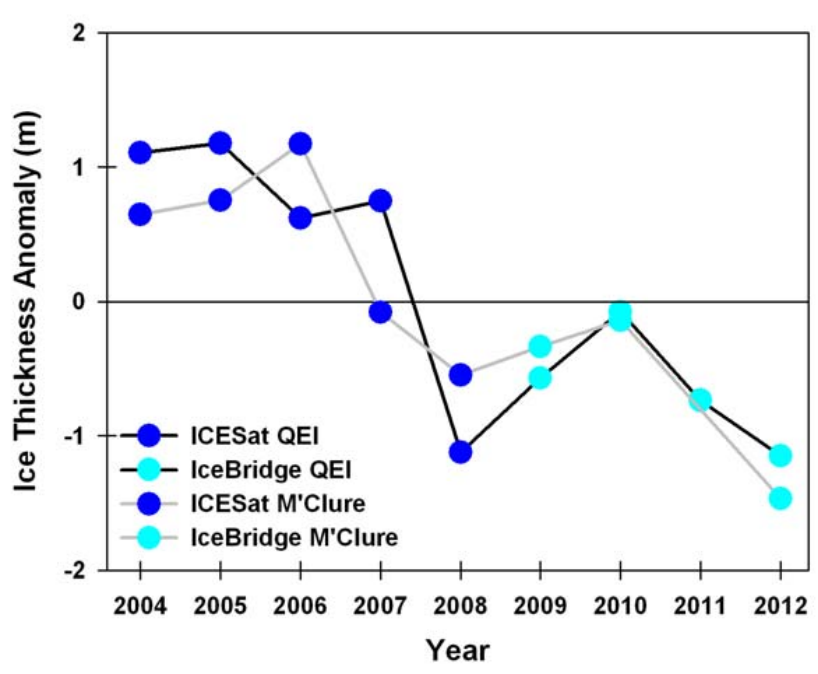

Fig. 14. Time series of ICESat and IceBridge winter Arctic sea ice thickness anomalies in the Canadian Basin just north of the Canadian Arctic Archipelago, 2004-2012. Anomalies are calculated with respect to the 2004-2012 period.

pre-2007 values (Table 1; Fig. 14). Indeed, the MYI at the Arctic Ocean-QEI exchange gates is certainly thicker than locations of the ICESat/IceBridge estimates (e.g. Bourke and Garrett, 1987), and more of this thicker ice likely flowed into the CAA. However, the latter provides additional support for thinner Arctic Ocean MYI flowing into the CAA. Maslanik et al. (2011) also reported considerable decreases in MYI age in the regional immediately north of the CAA since 2006.

It seems apparent that in both 2011 and 2012 sea ice was preconditioned to be susceptible to anomalous forcing, which resulted in extreme minima, even more so than in 1998 and 2007. It is however important to note that the lack of preconditioned ice thinning in the CAA does not always prevent record light years. For example, the ice in 1998 exhibited no evidence of preconditioning, yet an extreme minimum was still reached (Howell et al., 2010). Conversely, evidence of preconditioned thinning does not always prevent a heavy ice year from occurring. For example, because 1971 was a relatively light ice year, the 1972 melt season began with a low percentage of MYI within the CAA, and yet 1972 ended up being the heaviest ice year on record.

\section{Implications for navigating the Northwest Passage}

The extreme ice minima observed within the CAA in recent years have resulted in increased open water within the CAA and in turn the Northwest Passage. The time series of length of the navigation season and the mean MYI over the navigation season for the northern route of the Northwest Passage are shown in Fig. 15. The Canadian Ice Service defines the navigation season as "open" for any given week if the total ice extent within the route is less $60 \%$ of the total ocean

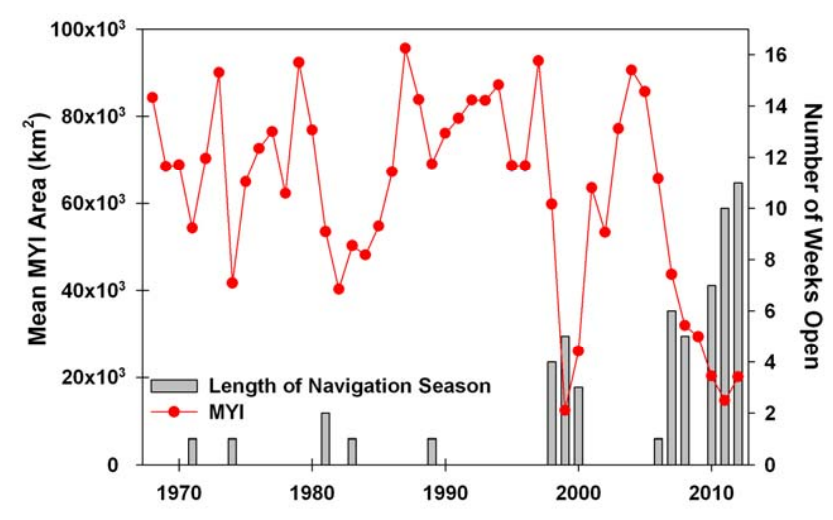

Fig. 15. Time series of the length of the navigation season for the northern route of the Northwest Passage and mean multi-year ice (MYI) area within the region, 1968-2012. The navigation season is defined by the Canadian Ice Service as a 17 -week time window from 25 June to 15 October.

area within the route. There is a strong inverse correlation between the length of the navigation and mean MYI area present over the shipping season of $r=-0.72$ (Fig. 15). The recent extreme light ice years within the CAA since 2007 are clearly associated with longer navigation seasons. The only other time period the northern route experienced a navigation season longer than 1-2 weeks was from 1998-2000, which was also associated with the extreme sea ice minima (i.e. 1998).

Recent studies suggest that the northern route of the Northwest Passage is expected be a viable shipping route by midcentury (e.g. Smith and Stephenson, 2013; Stephenson et al., 2013). Based on observations, there was certainly less MYI within the northern route over the shipping season in recent years (Fig. 15). However, MYI even in small concentrations is a serious hazard to transiting ships, and therefore caution should be taken with respect to the practical usage of the northern route in upcoming years. Specifically, the oldest and thickest MYI in the world lies on the north-facing coast of the CAA, and despite that fact that it may have thinned in recent years (Fig. 14), it will continue to flow southward into the CAA and subsequently into the Northwest Passage (Melling, 2002; Howell et al., 2009). In addition, the coupling of preconditioned ice thinning, rapid melt and anomalous atmospheric circulation is responsible for clearing of the northern route, but clearing is only temporary as MYI returns to regions where predominant atmospheric circulation prevails (Howell et al., 2009). As a result, the presence of MYI is likely to remain within the northern route despite extreme light ice conditions and a longer navigation season. Given the projected pattern of Arctic Ocean ice retreat (e.g. Wang and Overland, 2012), transit across the Arctic Ocean will likely be more viable than through the northern route of Northwest Passage, given the continued presence of MYI. 


\section{Conclusions}

We began this paper by first asking the questions: what were the processes that contributed to the new record extreme light ice years of 2011 and 2012, and how were they similar to or different from 1998 and 2007? The record low ice year of 2011 was associated with positive JJAS SAT and $K^{*}$ anomalies that facilitated rapid melt, together with July and August atmospheric circulation that restricted Arctic Ocean MYI inflow into the CAA. Although atmospheric circulation patterns between 1998 and 2011 were different, both restricted MYI inflow from the Arctic Ocean. The second lightest ice year of 2012 was also driven by positive JJAS SAT and $K^{*}$ anomalies that facilitated rapid melt, but August and September atmospheric circulation temporarily reduced the rapid rate of ice decline through MYI inflow from the Arctic Ocean. This positive ice area flux into the CAA prevented 2012 from surpassing the 2011 record. There was also evidence of preconditioned ice thinning prior to 2011 and 2012 (more so than 1998 and 2007), which made the sea ice more vulnerable to anomalous thermodynamic forcing, facilitating these extreme years.

The final question we posed was: could the CAA experience a heavy summer ice cover in upcoming years? Extreme heavy ice years in the CAA were found to be associated with (i) negative SAT and $K^{*}$ anomalies that reduced FYI decline over the melt season or (ii) moderate negative SAT and $K^{*}$ anomalies that allowed slightly more ablation of FYI, but where MYI inflow from the Arctic Ocean compensated for the extra FYI loss. The CAA could experience a heavy ice year if either of these processes was to occur again; however, this likelihood is reduced given the increased presence of FYI at the start of the melt season and if Arctic Ocean MYI flowing into the CAA is now thinner than several decades ago. The CAA's lack of MYI recovery since 2007 (evidenced by the fact that 5 of the 6 lightest years in the CAA since 1968 have occurred in the last $6 \mathrm{yr}$ ) and the associated trends towards warmer Arctic SAT (Kaufman et al., 2009; Berkryaev et al., 2011) and a longer Arctic melt seasons (Howell et al., 2009; Markus et al., 2009) also serve to reduce the probability of the CAA experiencing an extreme heavy ice year in the near future. If light sea ice conditions within the CAA persist, so will long navigation seasons with the northern route of the Northwest Passage, but the presence of MYI will still remain.
Acknowledgements. This work was funded by the Canadian Space Agency through the Government Related Initiatives Program. We would like to thank T. Markus and J. Miller at Cryospheric Sciences Laboratory NASA GSFC for providing the SMMR-SSM/I melt and freeze onset data. RADARSAT data for 1997, 1998, 2004 and 2007 were provided by the Alaska Satellite Facility, Fairbanks, Alaska. We also wish to thank J. Stroeve, J. Walsh, D. Bailey and two anonymous reviewers for their helpful comments on improving the quality of this paper.

Edited by: J. Stroeve

\section{References}

ACIA: Arctic Climate Impact Assessment, Cambridge, Cambridge University Press, 2004.

Agnew, T. and Howell, S.: The use of operational ice charts for evaluating passive microwave ice concentration data, Atmos. Ocean, 41, 317-331, doi:10.3137/ao.410405, 2003.

Agnew, T., Lambe, A., and Long, D.: Estimating sea ice area flux across the Canadian Arctic Archipelago using enhanced AMSRE, J. Geophys. Res., 113, C10011, doi:10.1029/2007JC004582, 2008.

Alt, B., Wilson, K., and Carrieres, T.: A case study of old ice import and export through Peary and Sverdrup channels in the Canadian Arctic Archipelago: 1998-2004, Ann. Glaciol., 44, 329338, doi:10.3189/172756406781811321, 2006.

AMSA: The Arctic Marine Shipping Assessment 2009 Report, Arctic Council, 2009.

Atkinson, D .E., Brown, R., Alt, B., Agnew, T., Bourgeois, J., Burgess, M., Duguay, C., Henry, G., Jeffers, S., Koerner, R., Lewkowicz, A. G., McCourt, S., Melling, H., Sharp, M., Smith, S., Walker, A., Wilson, K., Wolfe, S., Woo, M-K., and Young, K. L.: Canadian cryospheric response to an anomalous warm summer: A synthesis of the climate change action fund project "The State of the Arctic Cryosphere During the Extreme Warm Summer of 1998", Atmos. Ocean, 44, 347-375, doi:10.3137/ao.440403, 2006.

Berkryaev, R. V., Polyakov, I. V., and Alexeev, V. A.: Role of Polar Amplification in Long-Term Surface Air Temperature Variations and Modern Arctic Warming, J. Climate, 23, 3888-3906, doi:10.1175/2010JCLI3297.1, 2011.

Bourke, R. H. and Garrett, R. P.: Sea ice thickness distribution in the Arctic Ocean, Cold Reg. Sci. Technol., 13, 259-280, 1987.

Canadian Ice Service: Regional charts: History, accuracy, and caveats, Arch. Ser. Doc. Ser. 1, Ottawa, available at: http://ice. ec.gc.ca/IA_DOC/cisads_no_001_e.pdf(last access: 14. November 2013 ), 2007.

Canadian Ice Service: Sea Ice Climatic Atlas: Northern Canadian Waters 1981-2010, edited by: Canadian Ice Service, Ottawa, Canada, 995 pp., 2011.

Cavalieri, D., Parkinson, C., Gloersen, P., and Zwally, H. J., updated yearly, Sea Ice Concentrations from Nimbus-7 SMMR and DMSP SSM/I-SSMIS Passive Microwave Data, Boulder, Colorado USA: National Snow and Ice Data Center, 1996.

Comiso, J. C., Parkinson, C. L., Gersten, R., and Stock, L.: Accelerated decline in the Arctic sea ice cover, Geophys. Res. Lett., 35, L01703, doi:10.1029/2007GL031972, 2008. 
Holland, M. M., Bitz, C. M., and Tremblay, B.: Future abrupt reductions in the summer Arctic sea ice, Geophys. Res. Lett., 33, L23503, doi:10.1029/2006GL028024, 2006.

Howell, S. E. L., Tivy, A., Yackel, J. J., Else, B. G. T., and Duguay, C. R.: Changing sea ice melt parameters in the Canadian Arctic Archipelago: Implications for the future presence of multiyear ice, J. Geophys. Res., 113, C09030, doi:10.1029/2008JC004730, 2008

Howell, S. E. L., Duguay, C. R., and Markus, T.: Sea ice conditions and melt season duration variability within the Canadian Arctic Archipelago: 1979-2008, Geophys. Res. Lett., 36, L10502, doi:10.1029/2009GL037681, 2009.

Howell, S. E. L., Tivy, A., Agnew, T., Markus, T., and Derksen, C.: Extreme low sea ice years in the Canadian Arctic Archipelago: 1998 versus 2007, J. Geophys. Res., 115, C10053, doi:10.1029/2010JC006155, 2010.

Howell, S. E. L., Wohlleben, T., Dabboor, M., Derksen, C., Komarov, A., and Pizzolato, L.: Recent changes in the exchange of sea ice between the Arctic Ocean and the Canadian Arctic Archipelago, J. Geophys. Res., 118, 3595-3607, doi:10.1002/jgrc.20265, 2013.

Hudson, S. R., Granskog, M. A., Sundfjord, A., Randelhoff, A., Renner, A. H. H., and Divine, D. V.: Energy budget of first-year Arctic sea ice in advanced stages of melt, Geophys. Res. Lett., 40, 2679-2683, doi:10.1002/grl.50517, 2013.

Jeffers, S., Agnew, T., Alt, B., De Abreu, R., and McCourt, S.: Investigating the anomalous sea-ice conditions in the Canadian High Arctic (Queen Elizabeth Islands) during summer 1998, Ann. Glaciol., 33, 507-512, 2001.

Kalnay, E., Kanamitsu, M., Kistler, R., Collins, W., Deaven, D., Gandin, L., Iredell, M., Saha, S.,, White, G., Woollen, J., Zhu, Y., Chelliah, M., Ebisuzaki, W., Higgins, W., Janowiak, J., Mo, K. C., Ropelewski, C., Wang, J., Leetmaa, A., Reynolds, R., Jenne, R., and Joseph, D.: The NCEP/NCAR 40-year reanalysis project, B. Am. Meteorol. Soc., 77, 437-471, doi:10.1175/15200477(1996)077<0437:TNYRP>2.0.CO;2, 1996.

Kaufman, D. S., Schneider, D. P., McKay, N. P., Ammann, C. M., Bradley, R. S., Briffa, K. R., Miller, G. H., Otto-Bliesner, B. L., Overpeck, J. T., Vinther, B., and Arctic Lakes 2k Project Members: Recent warming reverses long-term Arctic cooling, Science, 325, 1236-1239, doi:10.1126/science.1173983, 2009.

Kistler, R., Kalnay, E.,, Collins, W., Saha, S., White, G., Woollen, J., Chelliah, M., Ebisuzaki, W., Kanamitsu, M., Kousky, V., van den Dool, H., Jenne, R., and Fiorino, M.: The NCEP-NCAR 50-year reanalysis: Monthly means CD-ROM and documentation, B. Am. Meteorol. Soc., 82, 247-267, doi:10.1175/15200477(2001)082<0247:TNNYRM>2.3.CO;2, 2001.

Komarov, A. S and Barber, D. G.: Sea ice motion tracking from sequential dual-polarization RADARSAT-2 images, IEEE T. Geosci. Remote, 1-12, doi:10.1109/TGRS.2012.2236845, 2013.

Krabill, W. B., Abdalati, W., Frederick, E. B., Manizade, S. S., Martin, C. F., Sonntag, J. G., Swift, R. N., Thomas, R. H., and Yungel, J. G.: Aircraft laser altimetry measurement of elevation changes of the Greenland ice sheet: Technique and accuracy assessment, J. Geodyn., 34, 357-376, doi:10.1016/S0264-3707(02)00040-6, 2002

Kurtz, N. T., Studinger, M., Harbeck, J., Onana, V., and Farrell, S.: IceBridge Sea Ice Freeboard, Snow Depth, and Thickness, Boul- der, Colorado USA: NASA DAAC at the National Snow and Ice Data Center, 2012.

Kurtz, N. T., Farrell, S. L., Studinger, M., Galin, N., Harbeck, J. P., Lindsay, R., Onana, V. D., Panzer, B., and Sonntag, J. G.: Sea ice thickness, freeboard, and snow depth products from Operation IceBridge airborne data, The Cryosphere, 7, 1035-1056, doi:10.5194/tc-7-1035-2013, 2013.

Kwok, R: Exchange of sea ice between the Arctic Ocean and the Canadian Arctic Archipelago, Geophys. Res. Lett., 33, L16501, doi:10.1029/2006GL027094, 2006.

Kwok, R. and Cunningham, G. F.: Contribution of melt in the Beaufort Sea to the decline in Arctic multiyear sea ice coverage: 1993-2009, Geophys. Res. Lett., 37, L20501, doi:10.1029/2010GL044678, 2010.

Kwok, R., Cunningham, G. F., Zwally, H. J., and Yi, D.: ICESat over Arctic sea ice: Interpretation of altimetric and reflectivity profiles, J. Geophys. Res., 111, C06006, doi:10.1029/2005JC003175, 2006.

Kwok, R., Cunningham, G. F., Zwally, H. J., and Yi, D.: Ice, Cloud, and land Elevation Satellite (ICESat) over Arctic sea ice: Retrieval of freeboard, J. Geophys. Res., 112, C12013, doi:10.1029/2006JC003978, 2007.

Kwok, R., Cunningham, G. F., Wensnahan, M., Rigor, I., Zwally, H. J., and Yi, D.: Thinning and volume loss of the Arctic Ocean sea ice cover: 2003-2008, J. Geophys. Res., 114, C07005, doi:10.1029/2009JC005312, 2009.

Lindsay, R. W., Zhang, J., Schweiger, A., Steele, M., and Stern, H.: Arctic sea ice retreat in 2007 follows thinning trend, J. Climate, 22, 165-176, doi:10.1175/2008JCLI2521.1, 2009.

Markus, T., Stroeve, J. C., and Miller, J.: Recent changes in Arctic sea ice melt onset, freezeup, and melt season length, J. Geophys. Res., 114, C12024, doi:10.1029/2009JC005436, 2009.

Maslanik, J. A., Fowler, C., Stroeve, J. C., Drobot, C., Zwally, J., Yi, D., and Emery, W: A younger, thinner Arctic ice cover: Increased potential for rapid, extensive sea-ice loss, Geophys. Res. Lett., 34, L24501, doi:10.1029/2007GL032043, 2007.

Maslanik, J. A., Stroeve, J. C., Fowler, C., and Emery, W.: Distribution and trends in Arctic sea ice age through spring 2011, Geophys. Res. Lett., 38, L13502, doi:10.1029/2011GL047735, 2011.

Melling, H.: Sea ice of the northern Canadian Arctic Archipelago, J. Geophys. Res., 107, 3181, doi:10.1029/2001JC001102, 2002.

Mesinger, F., Dimego, G., Kalnay, E., Mitchell, K., Shafran, P. C., Ebisuzaki, W., Jovic, D., Woollen, J., Rogers, E., Berbery, E. H., Ek, M. B., Fan, Y., Grumbine, R., Higgins, W., Li, H., Lin, Y., Manikin, G., Parrish, D., and Shi, W.: North American regional reanalysis, B. Am. Meteorol. Soc., 87, 342-360, 2006.

Nicolaus, M., Katlein, C., Maslanik, J., and Hendricks, S.: Changes in Arctic sea ice result in increasing light transmittance and absorption, Geophys. Res. Lett., 39, L24501, doi:10.1029/2012GL053738, 2012.

Ogi, M., Rigor, I. G., McPhee, M. G., and Wallace, J. M.: Summer retreat of Arctic sea ice: role of summer winds, Geophys. Res. Lett., 35, L24701, doi:10.1029/2008GL035672, 2008.

Parkinson, C. L. and Comiso, J. C.: On the 2012 record low Arctic sea ice cover: Combined impact of preconditioning and an August storm, Geophys. Res. Lett., 40, 1356-1361, doi:10.1002/grl.50349, 2013.

Perovich, D. K., Nghiem, S. V., Markus, T., and Schweiger, A.: Seasonal evolution and interannual variability of the local solar en- 
ergy absorbed by the Arctic sea ice-ocean system, J. Geophys. Res., 112, C03005, doi:10.1029/2006JC003558, 2007.

Perovich, D. K, Richter-Menge, J. A, Jones, K. F., and Light, B.: Sunlight, water and ice: extreme Arctic sea ice melt during the summer of 2007, Geophys. Res. Lett., 35, L11501, doi:10.1029/2008GL034007, 2008.

Simmonds, I. and Rudeva, I.: The great arctic cyclone of August 2012, Geophys. Res. Lett., 39, L23709, doi:10.1029/2012GL054259, 2012.

Smith, L. C. and Stephenson, S. R.: New Trans-Arctic shipping routes navigable by mid-century, Proc. Nat. Acad. Sci., 110, E1191-E1195, doi:10.1073/pnas.1214212110, 2013.

Sou, T. and Flato, G.: Sea ice in the Canadian Arctic Archipelago: Modeling the past (1950-2004) and the future (2041-60), J. Clim., 22, 2181-2198, doi:10.1175/2008JCLI2335.1, 2009.

Stephenson, S. R., Smith, L. C., Brigham, L. W., and Agnew, J. A.: Projected 21st-century changes to Arctic marine access, Clim. Change, 118, 885-899, doi:10.1007/s10584-012-0685-0, 2013.

Stroeve, J. C., Serreze, M., Drobot, S., Gearheard, S., Holland, M., Maslanik, J., Meier, W., and Scambos, T.: Arctic sea ice extent plummets in 2007, Eos Trans. AGU, 89, 89, 13-14, doi:10.1029/2008EO020001, 2008.

Stroeve J. C., Serreze, M., Holland, M., Kay, J., Maslanik, J., and Barrett, A.: The Arctic's rapidly shrinking sea ice cover: a research synthesis, Clim. Change, 110, 1005-1027, doi:10.1007/s10584-011-0101-1, 2011a.

Stroeve, J. C., Maslanik, J., Serreze, M. C., Rigor, I., Meier, W., and Fowler, D.: Sea ice response to an extreme negative phase of the Arctic Oscillation during winter 2009/2010, Geophys. Res. Lett., 38, L02502, doi:10.1029/2010GL045662, 2011 b.
Tivy, A., Howell, S. E. L., Alt, B., McCourt, S., Chagnon, R., Crocker, G., Carrieres, T., and Yackel, J. J.: Trends and variability in summer sea ice cover in the Canadian Arctic based on the Canadian Ice Service Digital Archive, 1960-2008 and 1968-2008, J. Geophys. Res., 116, C03007, doi:10.1029/2009JC005855, 2011.

Walsh, J. E., Chapman, W. L., and Portis, D. H.: Arctic cloud fraction and radiative fluxes in atmospheric reanalysis, J. Clim, 22, 2316-2334, 2009.

Wang, J., Zhang, J., Watanabe, E., Ikeda, M., Mizobata, K., Walsh, J. E., Bai, X., and Wu, B.: Is the dipole anomaly a major drier to record lows in Arctic summer sea ice extent?, Geophys. Res. Lett., 36, L05706, doi:10.1029/2008GL036706, 2009.

Wang, M. and Overland, J. E.: A sea ice free summer Arctic within 30 years - an update from CMIP5 models, Geophys. Res. Lett., 39, L18501, doi:10.1029/2012GL052868, 2012.

Wohlleben, T., Howell, S. E. L., Agnew, T., and Komarov, A.: SeaIce Motion and Flux within the Prince Gustaf Adolf Sea, Queen Elizabeth Islands, Canada during 2010, Atmos. Ocean, 51, 1-17, doi:10.1080/07055900.2012.750232, 2013.

Zhang, J., Lindsay, R., Schweiger, A., and Steele, M.: The impact of an intense summer cyclone on 2012 Arctic sea ice retreat, Geophys. Res. Lett, 40, 720-726, doi:10.1002/grl.50190, 2013. 